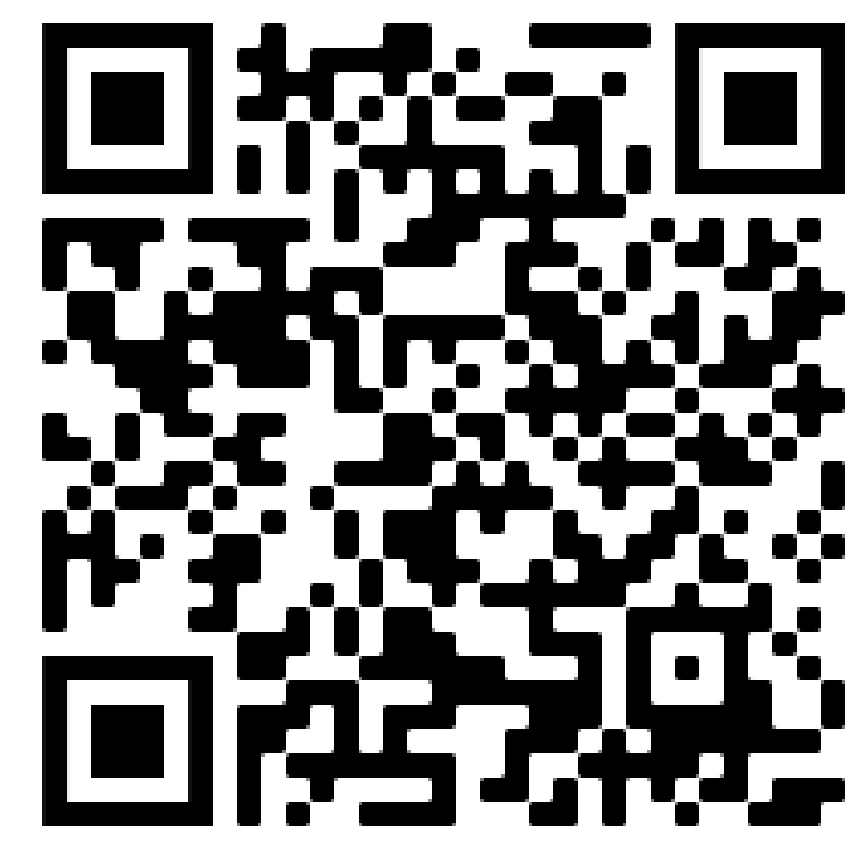

\title{
Série estudo para mãe
}

\author{
Ana Hortides ${ }^{1}$
}

1 Vive e trabalha no Rio de Janeiro. Artista visual e mestre pelo Programa de Pós-Graduação em Estudos Contemporâneos das Artes da Universidade Federal Fluminense (UFF), Rio de Janeiro, na qual se Graduou em Produção Cultural. Estudou na Escola de Artes Visuais do Parque Lage (EAV)/ RJ. Sua pesquisa se desenvolve em torno da casa, do íntimo, da figura e da representatividade da mulher, da potência política do doméstico.E-mail: anahortides@gmail.com 
Ana Hortides

Série Estudo para mãe 
$(1$ queixo possuía um pequenino furo. 

A berriga

saliente e postuindo um umbigo em londieues invejävis, pois se ender rava dentro de si mesmo, ocults.

pro por uem mín do lalor ou de pela pregado ao corpo e de estore do 
a brea

bem pequera, quase ná existia em seu rasto. Um' contor no quase imper eptivel aue se asse mellia aos lábios de sera mae. Portava uma língua de grande rachadura no meio e que falava demais. Possuía um bom senso de heemor que expandic $\theta$ cen lorno dos lábios im sorrisos maiores que eles poderiam earregar.

Us olhos

grandes e verdes possutam uma acastanhados a sou redor. As suces pupilas bram negras, peque nas e suiam água démais, lacrimejavam 
a sola dos pés earregava uma marca de nascenea 
A nula

nunca vi

4 colo

carregava algumas poucas rugas.

4 pescoeo

comum, passava des percebido. 
1 ealeanhar

redondo e com algu mas rachaduras

$\left[\begin{array}{l}- \\ +\end{array}\right.$ 
Us joellos

eom muitas cicatrizes. 
as mareas muitas, sem tamanho. 